IZA DP No. 9984

Gendered Entrepreneurship Networks

Simen Markussen

Knut Røed

June 2016

Forschungsinstitut zur Zukunft der Arbeit Institute for the Study of Labor 


\title{
Gendered Entrepreneurship Networks
}

\author{
Simen Markussen \\ Ragnar Frisch Centre for Economic Research \\ Knut Røed \\ Ragnar Frisch Centre for Economic Research \\ and IZA
}
Discussion Paper No. 9984
June 2016

\author{
IZA \\ P.O. Box 7240 \\ 53072 Bonn \\ Germany \\ Phone: +49-228-3894-0 \\ Fax: +49-228-3894-180 \\ E-mail: iza@iza.org
}

Any opinions expressed here are those of the author(s) and not those of IZA. Research published in this series may include views on policy, but the institute itself takes no institutional policy positions. The IZA research network is committed to the IZA Guiding Principles of Research Integrity.

The Institute for the Study of Labor (IZA) in Bonn is a local and virtual international research center and a place of communication between science, politics and business. IZA is an independent nonprofit organization supported by Deutsche Post Foundation. The center is associated with the University of Bonn and offers a stimulating research environment through its international network, workshops and conferences, data service, project support, research visits and doctoral program. IZA engages in (i) original and internationally competitive research in all fields of labor economics, (ii) development of policy concepts, and (iii) dissemination of research results and concepts to the interested public.

IZA Discussion Papers often represent preliminary work and are circulated to encourage discussion. Citation of such a paper should account for its provisional character. A revised version may be available directly from the author. 
IZA Discussion Paper No. 9984

June 2016

\section{ABSTRACT}

\section{Gendered Entrepreneurship Networks*}

In virtually all industrialized countries, women are underrepresented in entrepreneurship, and the gender gap exhibits a remarkable persistence. We examine one particular source of persistence, namely the prevalence of gendered networks and associated peer effects. We study how early career entrepreneurship is affected by existing entrepreneurship among neighbors, family members, and recent schoolmates. Based on an instrumental variables strategy, we identify strong peer effects. While men are more influenced by other men, women are more influenced by other women. We estimate that differences between male and female peer groups explain approximately half of the gender gap in early career entrepreneurship.

JEL Classification: L26, M13, J16

Keywords: $\quad$ early career entrepreneurship, peer effects, gender gap, instrumental variables

Corresponding author:

Knut Røed

The Ragnar Frisch Centre for Economic Research

Gaustadalléen 21

0349 Oslo

Norway

E-mail: knut.roed@frisch.uio.no

* This paper is part of the project "Entrepreneurship, Gender, and Social Capital" financed by the Norwegian Research Council (research grant no. 201336). Thanks to Rolf Golombek and seminar participants at IFAU, Uppsala, for valuable comments. 


\section{Introduction}

An entrepreneur is a person who seeks to create his/her own workplace, and potentially also generates workplaces for others. In all industrialized economies, there are considerably fewer female than male entrepreneurs (Kelley et al., 2012). The existing literature offers no generally accepted explanation for this gender gap. Its universality points toward fundamental gender differences related to, e.g., risk aversion (Jianakoplos og Bernasek, 1998; Byrnes et al., 1999; Croson og Gneezy, 2009; Borghans et al., 2009) or in attitudes toward competition (Niederle og Vesterlund, 2007; Gneezy et al., 2003; Bönte and Piegeler, 2013). However, although there is some evidence indicating a genetic component in these differences (Sapienza et al., 2009), it appears probable that they to some extent are culturally inherited, and therefore will diminish over time as traditional gender roles are moderated. Yet, it is not generally the case that the gender gap in entrepreneurship is particularly small in labor markets considered to have come far in terms of gender equality. The country that we study in the present paper - Norway - illustrates this point. In terms of labor force participation, Norway is one of the most gender-equal societies in the world: $48 \%$ of the active labor market participants are female (OECD, 2014). In terms of entrepreneurship, it is one of the most gender-unequal societies: Only $25 \%$ of the entrepreneurs are female (Berglann et al., 2011). And only a small fraction of this gender gap can be accounted for by observed individual characteristics, such as education and industry (Berglann et al., 2013).

One possible explanation for the large and persistent gender gaps in entrepreneurship activities is that the historically inherited male dominance in this area is preserved through gendered social networks and peer influences. In order to start a new business, one may need contacts, informants, customers, and (maybe) investors, and probably also advice and encouragement from existing entrepreneurs. Networks constitute a stock of social capital that can deliver these intangible "services". In addition, they can motivate and educate for entrepreneurship during the formative adolescence years (Guiso et al. 2015). The existence of role models may also be important for occupational choices, and human beings tend to look for same-sexed role models; see, e.g., Ruef et al. (2003) and Bosma et al. (2012). ${ }^{1}$ Hence, the fact that men tend to have much more existing entrepreneurs in their social networks is likely to

\footnotetext{
${ }^{1}$ Based on survey data from 29 different countries, Verheul et al. (2012) have provided empirical evidence indicating that the gender gap in entrepreneurship is more about the cognitive stage of "wanting it" than about the behavioral stage of "doing it".
} 
motivate them for own entrepreneurship attempts, and may also give them a potential advantage once started.

There is already an existing literature indicating that spatial variations in entrepreneurship are extremely persistent over time. Fritsch and Wyrwich (2014), for example, show that selfemployment rates observed in German regions as far back as in 1925 are robust predictors for the regional patterns of entrepreneurship today. And recent studies from Sweden (Giannetti and Simonov, 2009; Andersson and Larsson, 2016) and Denmark (Nanda and Sørensen, 2008) indicate a prominent role for social networks and peer influences in explaining spatial persistence in entrepreneurship: The higher is the entrepreneurship activity among neighbors or colleagues, the higher is the probability that yet another person embarks on entrepreneurship, ceteris paribus. Thus, initial spatial differences tend to persist or even become enlarged over time. Existing evidence also indicates that personal networks may have a larger influence on entrepreneurship behavior in small communities than in large ones; see Bauernschuster et al. (2010). This may potentially explain why gender-differences appear to be particularly persistent in a sparsely populated and highly decentralized country like Norway.

The research question we address in the present paper is whether - and to which extent - gendered social networks, family linkages, and peer influences also can explain the persistence of the gender gap in entrepreneurship. To identify and estimate peer effects is known to be a challenging methodological problem; see, e.g., Angrist (2013) for critical discussion. A number of confounding factors may exist, such as endogenous geographical migration and unobserved local variations in industry-composition. Moreover, when considering how a group’s aggregate behavior influences the behavior of its individual members, there is what Manski (1993) labelled a reflection problem: It is difficult to disentangle the group's effects on its individual members from the fact that the group's behavior is a mechanical reflection of its members' behavior.

Our analysis is based on administrative register data from Norway with population-wide annual information about individual labor market statuses from 2002 through 2012. We examine peer influences on early career entrepreneurship within networks confined to neighborhoods, families, and schoolmates. Our analysis population consists of labor market entrants, which we follow for up to 10 years after entry. We investigate how their occupational choices - in terms of regular employment or entrepreneurship - are affected by the corresponding choices already made by their older peers. In this part of the exercise, the peers' behaviors are strictly 
pre-determined, and can, with appropriate controls, be interpreted as exogenous. In addition, we examine how their own occupational choices are affected by those of their schoolmates or fellow students (hereafter referred to as schoolmates). These choices are to some extent made simultaneously, and peer influences can run both ways. We deal with this and the associated reflection problem by using the pre-determined entrepreneurship activity among the schoolmates' parents as instruments. In this exercise, we exploit a recent finding reported by Lindquist et al. (2015) that the intergenerational transmission of entrepreneurship propensity is heavily gendered: Mothers influence daughters whereas fathers influence sons. This clearly also represents a channel for making the gender gap persistent.

Our findings consistently confirm the importance of peer effects at all levels. The incidence of an early career entrepreneurship endeavor is influenced by existing entrepreneurship rates in the local community, the family, and in the group of recent schoolmates. Close family has a larger influence than more distant family. Close neighbors have a larger influence than more distant neighbors. And importantly: same-sex peers generally have larger influence than opposite-sex peers. The latter implies that men have much more entrepreneurs in their most influential peer groups than women have. We estimate that this explains approximately $50 \%$ of the gender gap in early career entrepreneurship. The statistical uncertainty is considerable, however, and a $90 \%$ confidence interval on the fraction of the gender gap that is accounted for by differences between male and female peer groups ranges from 21 to $81 \%$.

\section{Background and data}

The foundation for our analysis is (encrypted) administrative register data from Norway, combining employer-employee registers with information on earnings and business income and firm ownership. For each year 2002-2012, we use these data to identify regular employment and entrepreneurship activities. Our entrepreneurship definition is considerably wider than the self-employment concept often encountered in the economics literature, as it also includes persons who are employed in limited liability firms in which they have a large ownership share (more than $30 \%$ ), either directly or indirectly through other firms; see Berglann et al. (2011) for details. We extend the Berglann et al. (2011) definition somewhat, however, by also including persons who have regular employment as their main source of personal income, yet still operate an active business as self-employed (regardless its size and profitabil- 
ity). ${ }^{2}$ The motivation behind this extension is that we wish to capture nascent entrepreneurship and entrepreneurship endeavors that are not necessarily successful.

Figure 1 shows for men and women, respectively, annual entrepreneurship rates in Norway from 2002 to 2012. In panel (a), the rates are conditional on economic self-sufficiency, defined as having annual earnings from employment and/or entrepreneurship exceeding a subsistence level of NOK 180,000 (approximately \$21,200). ${ }^{3}$ In panel (b), they are unconditional. Both conditional and unconditional entrepreneurship rates are approximately three times as high for men as for women. There has, however, been a convergence during the period we look at, with slightly increasing female entrepreneurship rates and slightly decreasing male entrepreneurship rates.
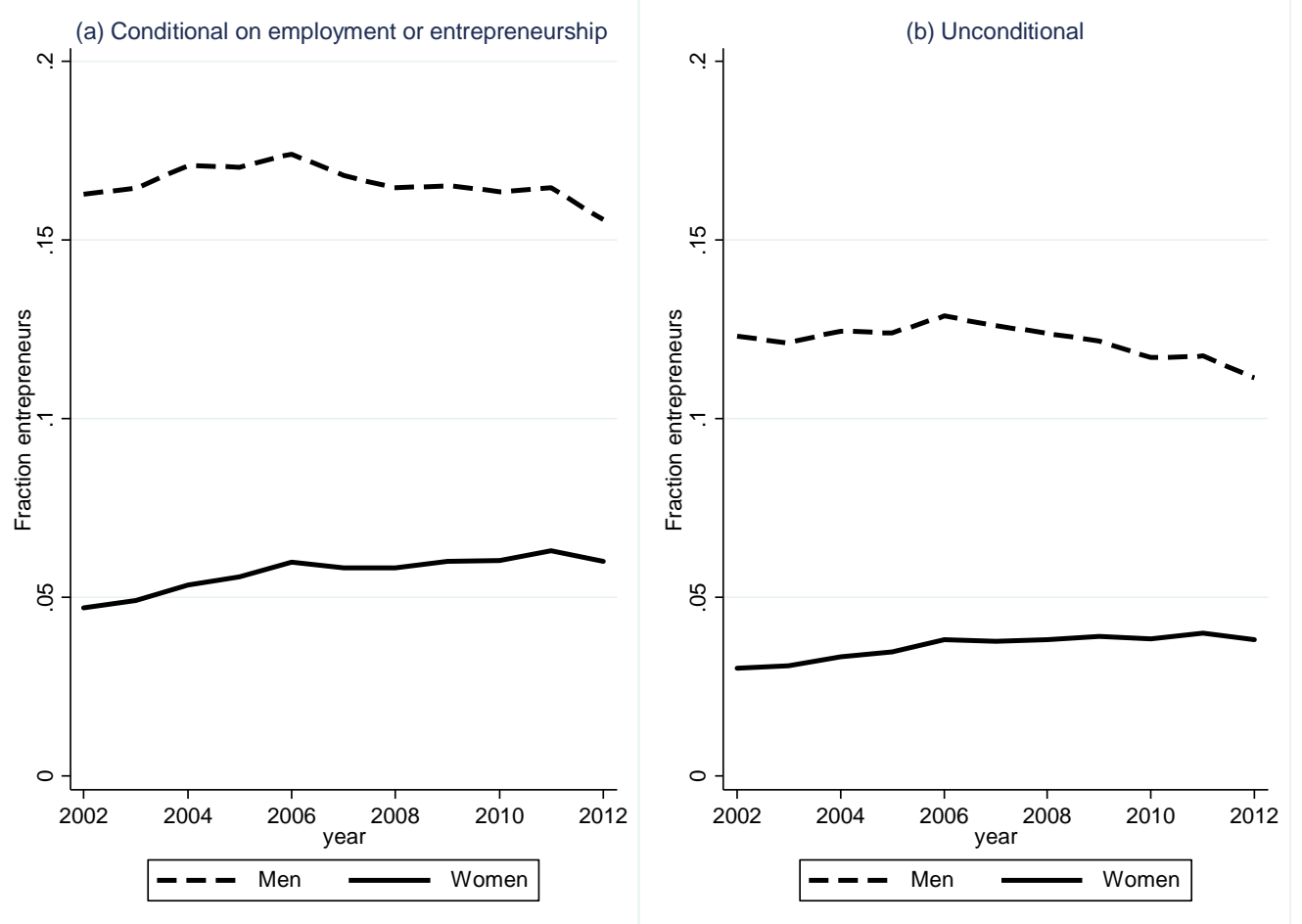

\section{Figure 1. Entrepreneurship rates by gender 2002-2012}

Note: The conditional entrepreneurship rate in panel (a) is defined as the number of persons aged 18-66 engaged in any form of entrepreneurial activity (incorporated or unincorporated) divided by the total number of economically active persons (employees and entrepreneurs) in the same age group. The unconditional rate in panel (b) is defined as the same number of persons with entrepreneurial activity divided by the total population aged 18-66.

\footnotetext{
${ }^{2}$ We define an "active business" as a business with at least some recorded economic activity during the year in the sense that associated earnings are strictly non-zero.

${ }^{3}$ This threshold corresponds to approximately one third of average full-year-full-time earnings in Norway. Monetary amounts reported in this paper are inflated to 2016-value, and NOK is converted to $\$$ based on the exchange rate applying in March 2016 (\$ 1=NOK 8.5).
} 
(a) Men

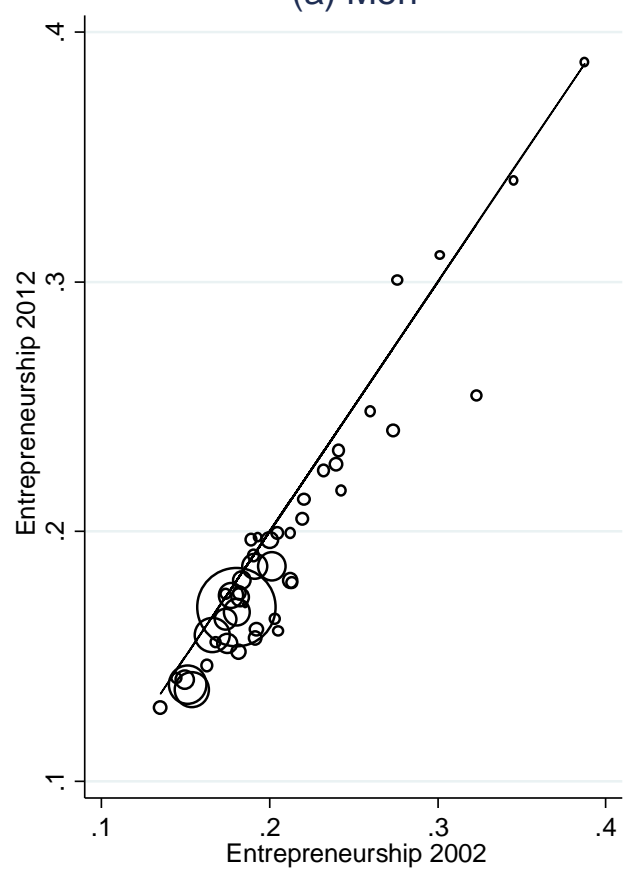

(b) Women

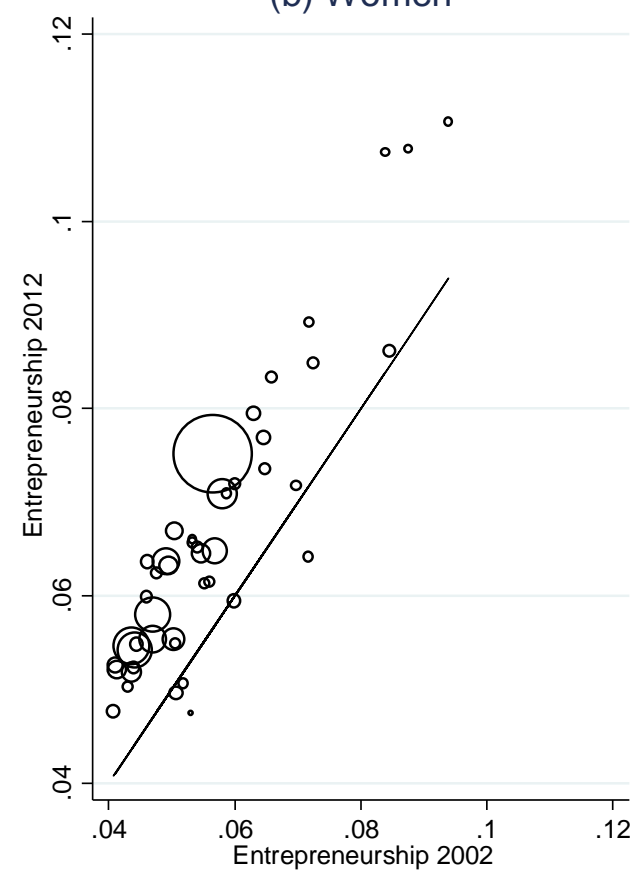

Figure 2. Entrepreneurship rates by travel-to-work area (TWA). 2002 and 2012.

Note: Circle sizes are proportional to TWA size (average number of inhabitants over the two involved years). The lines are the 45 degree lines.

There are considerable geographical differences in the entrepreneurship rate, and these differences are highly persistent over time. This is illustrated in Figure 2, where we plot genderspecific entrepreneurship rates by travel-to-work area (TWA) in 2002 against the corresponding rates in 2012. ${ }^{4}$ The circle sizes in Figure 2 are proportional to the number of inhabitants in each TWA. It is clear that the geographical distribution of entrepreneurship in Norway was virtually unchanged over this 10 year period, and that the positive shifts in female entrepreneurship rates have been of similar magnitude in all parts of the country.

Our data contain rich information on family linkages, education (including school identity, type/level, and graduation year), places of residence (at the level of small neighborhoods), nationality, and demographic characteristics. These dimension of the data will be used to establish the individually assigned peer groups that potentially play a role in encouraging or

\footnotetext{
${ }^{4}$ We use a partition with 46 such regions in Norway, with approximately 110,000 inhabitants on aver-
} age; see Bhuller (2009). 
discouraging entrepreneurship endeavors. Provided that some employment or entrepreneurship activity is recorded, the data also contain information about the chosen industry.

\section{Empirical approach}

The starting point of our empirical analysis is the group of persons who completed their education in 2001-2007. We interpret an educational career as completed in a given semester if a person was registered as a pupil/student that semester, but not in any of the following six semesters. ${ }^{5}$ We refer to the year of completion as the graduation year, irrespective of whether a grade was obtained or not. We collect information about subsequent labor market states and construct annual entrepreneurship indicators for each year after the graduation year and until 2012. Hence, for these individuals we have panels of 5-10 consecutive outcome observations (depending on graduation year), each indicating entrepreneurial activity. By studying labor market entrants, we ensure that we model occupational choices from the very start of the labor market career, at which point they are not governed by the persistence of previously chosen states, whereas their older peers' entrepreneurship behaviors can safely be considered exogenous. This way we ensure that while the members of our analysis population may have been affected by ongoing entrepreneurship activities in their local communities, they have not yet been able to influence these activities themselves. We thus have a hierarchical model, whereby the "old" may affect the behavior of the "young", but not vice versa, and we circumvent the reflection problem discussed by Manski (1993). Our focus on early career entrepreneurship also implies that we can rather directly examine how gender patterns in entrepreneurship are (or are not) transferred across generations. We have a simultaneity problem in relation to one potentially important peer group, though, namely that consisting of schoolmates. As we explain in more detail below, we deal with this by applying an instrumental variables strategy.

The way we have constructed the data ensures that all graduation cohorts can be followed for at least five years. In order to examine the impact of various peer groups' influence on own entrepreneurship behavior, we define as our main outcome variable an indicator for at least some entrepreneurship activity within the first five years after the year of graduation. We return to alternative outcomes later on in the form of a year-by-year analysis where we exploit each graduation cohort as long as we are able to observe it.

\footnotetext{
${ }^{5}$ More precisely, we require that an education lasting at least six months ended and that no education lasting more than three months was recorded the next three years.
} 
Table 1 shows some descriptive statistics for our analysis population. We follow around 213,000 school graduates for five years or more. During the first five years, $10.6 \%$ of the men, and $5.7 \%$ of the women has been engaged in some form of entrepreneurship. Hence, the gender gap at this stage of the labor market career is 4.9 percentage points.

Table 1. Descriptive statistics analysis sample

\begin{tabular}{lcc}
\hline & Men & Women \\
Number of graduates & 113,156 & 101,046 \\
Age at graduation & 22.1 & 22.7 \\
\cline { 2 - 3 } Educational level (\%) & & \\
$\quad \begin{array}{l}\text { Primary education or uncompleted secondary education } \\
\text { Secondary education }\end{array}$ & 31.9 & 25.0 \\
$\quad$ College/University & 44.5 & 34.9 \\
$\begin{array}{l}\text { Any economic activity (employment or entrepreneurship) } \\
\text { during first five years (\%) }\end{array}$ & 23.6 & 40.1 \\
Any entrepreneurship activity during first five years (\%) & 83.3 & 82.3 \\
\hline
\end{tabular}

Figure 3 presents unconditional employment and entrepreneurship propensities by years since graduation for the 2001-2002 graduation cohorts. We focus on these two cohorts in this particular graph for the reason that they can be followed for a full 10-year period. Looking at panel (b) it is evident that entrepreneurship rates, as well as the gender gap, increase rather monotonically with years since graduation. ${ }^{6}$

In figure 4, we plot the incidences of early career entrepreneurship during the first five years after graduation against the existing same-sex entrepreneurship rates (in the graduation year) in the residential travel-to-work area (TWA). Again, a remarkable pattern of persistence emerges. Early career entrepreneurship is higher the higher the local rate of same-sex entrepreneurship is to start with.

The descriptive patterns presented so far do of course not necessarily reflect peer effects. They may also reflect other sources of geographical variations in educational/occupational choices and/or industry composition. To isolate and estimate the peer effects, we set up a statistical model designed to eliminate potentially confounding factors.

\footnotetext{
${ }^{6}$ Note that the conspicuously high female employment rate in the first two years after graduation (panel (a)), as well as the subsequent drop, may be explained by the combination of a generous parental leave scheme in Norway providing (almost) full wage replacement for a year, but (in the period covered here) only conditional on at least six months of regular employment.
} 
(a) Employment

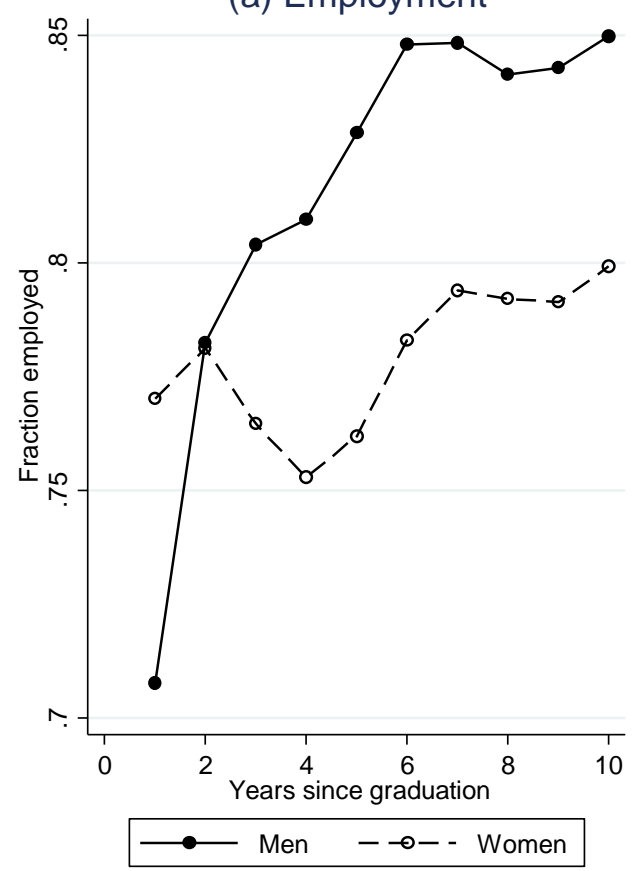

(b) Entrepreneurship

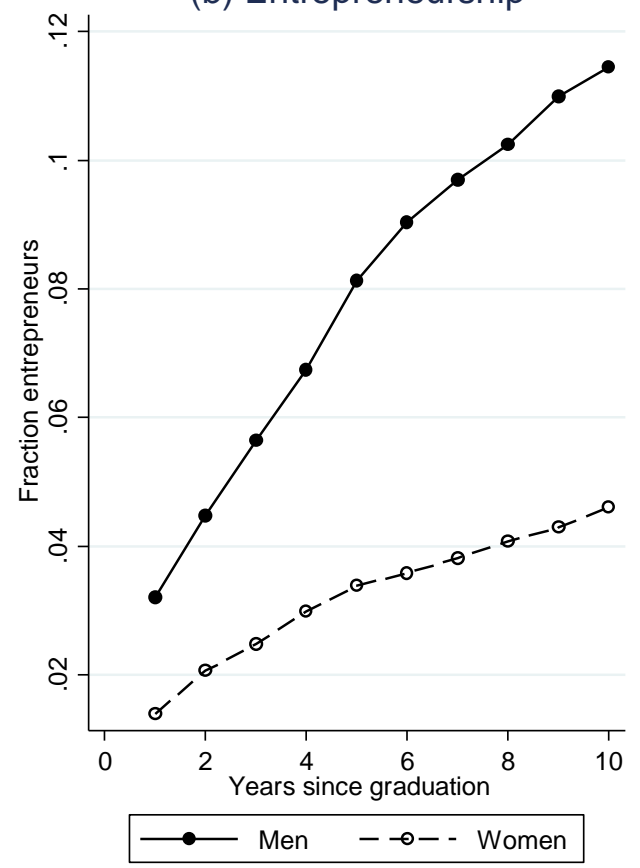

Figure 3. Unconditional rates of regular employment and entrepreneurship by years since graduation (2001-2002 graduation cohorts).
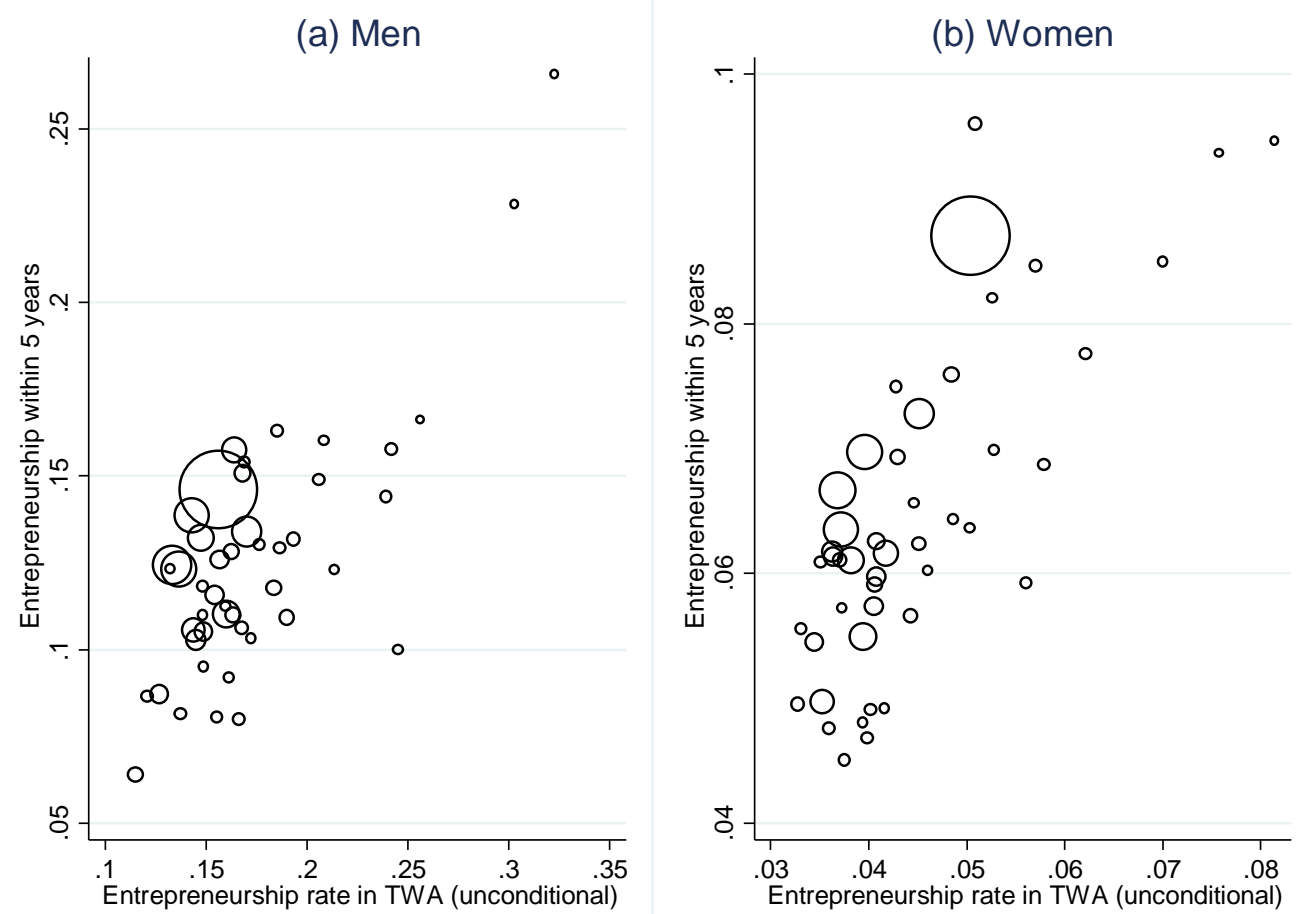

Figure 4. Gender-specific graduation-year entrepreneurship rate in travel-to-work-area (TWA) and fraction with early career entrepreneurship during first five years after graduation. 
Let $E n t_{i}$ be our outcome variable for individual $i$, which in the main part of our analysis is equal to 1 if some entrepreneurship activity has been recorded (either as a main activity or as one of multiple activities) within five years after school completion, and 0 otherwise. We then set up regressions of the following form separately for men and women:

$$
\text { Ent } t_{i}=\sum_{k}\left(\gamma_{m k} e_{m k i}+\gamma_{w k} e_{w k i}\right)+\text { controls }+\varepsilon_{i} .
$$

The right-hand-side variables of interest are the indicators for entrepreneurship behavior in the peer groups relevant for person $i$, denoted $e_{m k i}$ and $e_{w k i}$, where the subscript $k$ indicates the type of peer group and the subscripts $(m, w)$ distinguish men from women. We use peer groups of three different types: Neighbors, family, and schoolmates. The groups are in all cases defined such that they exclude the reference person. The groups and their associated indicators are defined as follows:

Neighbors: We distinguish between close and distant neighbors, with both groups identified on the basis of residential addresses in the year of graduation. By "close neighbors", we mean persons living in the same "basic statistical unit” ("grunnkrets") as defined by Statistics Norway. These are designed to resemble genuine neighborhoods where residents are likely to interact. ${ }^{7}$ There are 13,700 basic statistical units in Norway, each populated by around 350 individuals on average. By “distant neighbors”, we mean persons living in adjacent neighborhoods belonging to the same "statistical tract” (“delområder”). These are also drawn up by Statistics Norway, and are designed to encompass neighborhoods that share common service/shopping center facilities. A typical statistical tract comprises around 8-9 neighborhoods and 3,100 inhabitants. As indicators for the two neighbor groups' entrepreneurship behavior we use the overall fraction of entrepreneurs in the population aged between 30 and 61 in the year of own graduation (excluding own family members).

Family members: For family members, we also distinguish between close and more distant relatives. By “close relatives”, we mean parents and siblings. By “distant relatives”, we mean uncles, aunts, and (first) cousins. As indicator for the family members' entrepreneurship behavior, we again use the fractions involved in entrepreneurship at the time of own (person $i$ 's) graduation.

\footnotetext{
${ }^{7}$ For a more thorough description of the neighborhood concept and other geographical entities used in this paper, see Statistics Norway (1999).
} 
Schoolmates: We identify schoolmates as the persons who graduated from the same school/college/university with exactly the same education (based on a six-digit education code) in the same semester. Almost by definition, there are no entrepreneurs in this group in the year of graduation. As indicators for entrepreneurship behavior, we use the fraction of schoolmates that has engaged in some form of entrepreneurship within five years after graduation.

Equation (1) embodies at least two potential identification challenges. The first is that of confounding factors: There may exist local or education-specific variations in entrepreneurship propensity that have nothing to do with peer effects. We deal with this challenge by including extensive sets of control variables. The control variables in (1) incorporate a large number of fixed effects. In a baseline model, they include:

- Age-at-graduation fixed effects (age=18, 19, .,,29),

- School fixed effects (1,166 different educational institutions),

- Education fixed effects for the last observed educational track (219 different categories based on a three-digit international standard classification of education (ISCED)),

- Travel-to-work area by graduation-semester fixed effects (460 different combinations),

- For immigrants: Region-of-origin-country fixed effects (5 different regions).

In a robustness analysis below, we extend the control variable sets even further by using more detailed educational controls and also including industry dummy variables (for the subset of observations where employment or entrepreneurship has been recorded).

The second challenge is that of reverse causality: While the peer variables for neighbors and family members are strictly predetermined with respect to the outcomes, this is not the case for schoolmates. These variables are endogenous, in that they may have been affected by - as well as affected - the dependent variable in (1). To deal with the resultant simultaneity problem, we use an instrumental variable strategy. As instruments for the contemporaneous entrepreneurship activities in the groups of schoolmates we use the fractions of their mothers and fathers that were engaged in entrepreneurship at the time of graduation. Since mothers and fathers may affect sons and daughters differently, this gives us four instruments for the two endogenous peer group variables (i.e., entrepreneurship rates among fathers to sons, fathers to daughters, mothers to sons, and mothers to daughters). The identifying assumption is that the conditional correlation between a person's own entrepreneurship activities and that of the 
parents to his/her schoolmates is governed by the latter's impact on entrepreneurship among their own offspring only.

Another point to note is that while it is natural to interpret causal relationships between the different groups' entrepreneurship propensities and the outcome variable as somehow related to peer effects, this is probably not the most important transmission mechanism for the influence of close family members. In particular, the effects identified for own parents are also likely to reflect the transmission of financial wealth and (in some cases) the inheritance of family firms.

Descriptive statistics for the various peer groups are presented in Table 2. Their sizes of course differ enormously, with the average numbers varying from only 1-3 for the two familygroups, 25-50 for the schoolmate groups, around 150 for the close neighbor groups and more than 1,000 for the groups of distant neighbors. It is also notable that entrepreneurship rates in the male peer groups are much higher than in the female peer groups.

Table 2. Descriptive statistics for peer groups

\begin{tabular}{|c|c|c|c|c|c|}
\hline & $\begin{array}{c}\text { I } \\
\text { Close } \\
\text { neighbors }\end{array}$ & $\begin{array}{c}\text { II } \\
\text { Distant } \\
\text { neighbors }\end{array}$ & $\begin{array}{c}\text { III } \\
\text { Close } \\
\text { family }\end{array}$ & $\begin{array}{c}\text { IV } \\
\text { Distant } \\
\text { family }\end{array}$ & $\begin{array}{c}\mathrm{V} \\
\text { School- } \\
\text { mates }\end{array}$ \\
\hline \multicolumn{6}{|l|}{ Men: } \\
\hline \multicolumn{6}{|l|}{ Male peer groups } \\
\hline Average size & 151 & 1,075 & 1.23 & 3.38 & 49 \\
\hline Average entrepreneurship indicator & 0.16 & 0.16 & 0.13 & 0.10 & 0.09 \\
\hline \multicolumn{6}{|l|}{ Female peer groups } \\
\hline Average size & 151 & 1,067 & 1.30 & 3.25 & 25 \\
\hline Average entrepreneurship indicator & 0.04 & 0.04 & 0.03 & 0.03 & 0.03 \\
\hline \multicolumn{6}{|l|}{ Women: } \\
\hline \multicolumn{6}{|l|}{ Male peer groups } \\
\hline Average size & 155 & 1,108 & 1.23 & 3.32 & 26 \\
\hline Average entrepreneurship indicator & 0.16 & 0.16 & 0.13 & 0.10 & 0.09 \\
\hline \multicolumn{6}{|l|}{ Female peer groups } \\
\hline Average size & 154 & 1,096 & 1.30 & 3.21 & 58 \\
\hline Average entrepreneurship indicator & 0.04 & 0.04 & 0.03 & 0.03 & 0.05 \\
\hline
\end{tabular}

In order to specify our instrumental variables (2SLS) model, let $\left(e_{m s i}, e_{w s i}\right)$ denote the entrepreneurship rates for person i's male $(m)$ and female $(w)$ schoolmates $(s)$, respectively. The first step equations then take the following form:

$$
e_{g s i}=\pi_{f s}^{g} e_{i}^{f s}+\pi_{f d}^{g} e_{i}^{f d}+\pi_{m s}^{g} e_{i}^{m s}+\pi_{m d}^{g} e_{i}^{m d}+\text { controls }+\xi_{i}, \quad g=m, w,
$$

where $\left(e_{i}^{f s}, e_{i}^{f d}, e_{i}^{m s}, e_{i}^{m d}\right)$ are the observed entrepreneurship rates observed for the respective groups' parents, where the superscripts indicate fathers to sons $(f s)$, fathers to daughters $(f d)$, 
mothers to sons $(m s)$, and mothers to daughters $(m d)$. Hence, our first step equation is designed to exploit the findings reported by Lindquist et al. (2015) that fathers and mothers influence their sons and daughters very differently.

Let $\left(\hat{e}_{m i}, \hat{e}_{w s i}\right)$ be the predictions from an ordinary least square (OLS) estimation of Equation (2). Our second step equation then becomes

$$
E n t_{i}=\sum_{k \neq s}\left(\gamma_{m k} e_{m k i}+\gamma_{w k} e_{w k i}\right)+\gamma_{m s} \hat{e}_{m s i}+\gamma_{w s} \hat{e}_{w s i}+\text { controls }+\zeta_{i}
$$

\section{Main results}

Our main estimation results are presented in Table 3. For comparison, we present both the (naïve) OLS results and the second stage 2SLS results in panel A, whereas the first stage 2SLS results are presented in panel B. As expected, the estimates from the OLS (columns I and III) and 2SLS (columns II and IV) models in panel A are almost identical for all the peer influences, except for the two endogenous schoolmate peer entrepreneurship rates where the 2SLS estimates are somewhat larger than the OLS estimates. In our discussion of the results, we focus entirely on the 2SLS estimates.

Before we turn to the results of substantive interest, we note from the first stage estimates in panel B that the instruments based on the (predetermined) entrepreneurship behavior of the peers' parents do have a considerable influence on the schoolmates' entrepreneurial activities, and that fathers are relatively more important for sons than for daughters. We present two different F-statistics for the power of the instruments. The partial F-statistic gives the conventional test for the joint impact of the excluded instruments separately for each of the endogenous variables. They suggest that the instruments are relatively strong, with a possible exception for the instruments for female schoolmates in the male regression (which has an Fstatistic slightly below 10). However, with multiple endogenous variables, the partial Fstatistics are unable to detect cases in which interdependencies imply that it is difficult to identify which of the endogenous variables they operate through. We therefore also provide F-statistics proposed by Sanderson and Windmeijer (2016), which are conditional on the other endogenous variable. These statistics turn out to be well above conventional threshold levels for weak instruments (Stock and Yogo, 2005). Hence, our instruments appear to nicely disentangle the peer influences of male and female schoolmates. 
Table 3. Estimated peer effects (standard errors in parentheses)

\begin{tabular}{cccccc} 
& Men & & \multicolumn{3}{c}{ Women } \\
\hline I & & II & III & IV
\end{tabular}

A. OLS/Second step 2SLS. Dependent variable = Own entrep. within five years after graduation

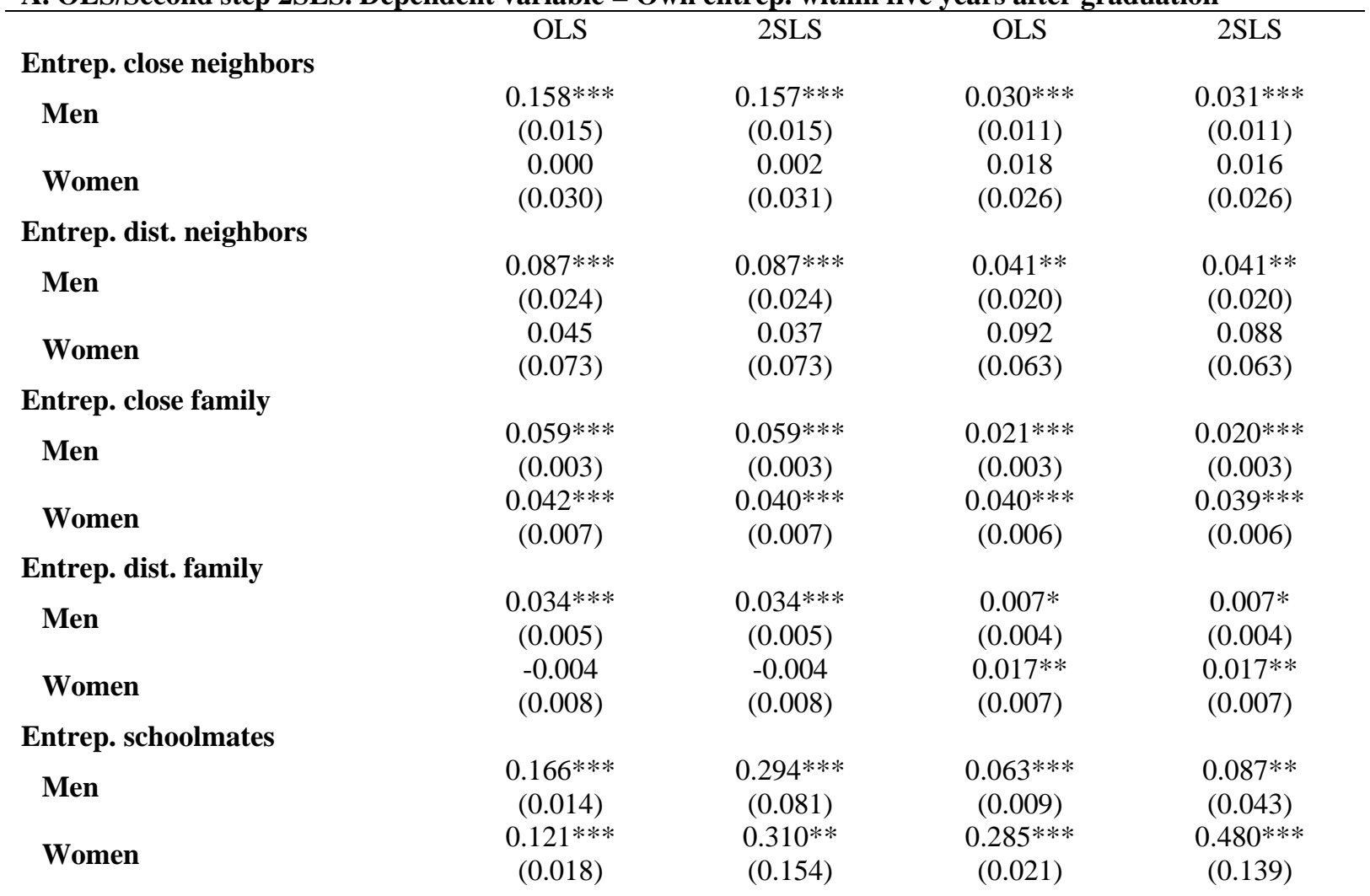

B. First step 2SLS. Dependent variable = Average entrep. in peer group within five years after graduation

\begin{tabular}{lcccc}
\hline & $\begin{array}{c}\text { Male school- } \\
\text { mates }\end{array}$ & $\begin{array}{c}\text { Female school- } \\
\text { mates }\end{array}$ & $\begin{array}{c}\text { Male school- } \\
\text { mates }\end{array}$ & $\begin{array}{c}\text { Female school- } \\
\text { mates }\end{array}$ \\
Entreprep. parents & $0.085^{* * *}$ & -0.000 & $0.102 * * *$ & -0.001 \\
Fathers of sons & $(0.006)$ & $(0.004)$ & $(0.014)$ & $(0.004)$ \\
Mothers of sons & $0.049^{* * *}$ & -0.001 & $0.063^{* * *}$ & 0.010 \\
Fathers of daughters & $(0.012)$ & $(0.006)$ & $(0.023)$ & $(0.007)$ \\
& -0.005 & $0.032^{* * *}$ & $0.016^{* *}$ & $0.037^{* * *}$ \\
Mothers of daughters & $(0.004)$ & $(0.006)$ & $(0.008)$ & $(0.006)$ \\
F-statistic excluded instruments & 0.003 & $0.021^{* *}$ & 0.014 & $0.054^{* * *}$ \\
(partial) & $(0.008)$ & $(0.009)$ & $(0.017)$ & $(0.013)$ \\
F-statistic excluded instruments & 53.9 & 9.4 & 22.1 & 19.0 \\
(conditional) & 62.8 & 13.4 & 22.5 & 26.2 \\
Number of observations (N) & 113,156 & 113,156 & 101,046 & 101,046 \\
\hline
\end{tabular}

Note: All regressions include indicator variables for age-at-graduation (12 categories), graduation school (1,166 categories), education level/type (219 categories), travel-to-work area by graduation (460 categories), and originregion for first- and second generation immigrants (5 categories). Standard errors are computed with a two-way cluster on neighborhood (close neighbors) and schoolmate/co-student peer group. ${ }^{*}(* *)(* * *)$ indicate statistical significance at the 10(5)(1) \% levels. 
Taken at face value, the second stage coefficients can be interpreted as the estimated change in early career entrepreneurship arising from a change in the respective peer groups' entrepreneurship rate from 0 to 1 . Note, however, that the actual variation in the data - and thus the margin used for identification - varies enormously across the different peer groups. For the smallest peer groups (close family), the variation in the data actually goes from 0 to 1 , whereas for the larger groups (distant neighbors) it typically goes from around 0.10 to 0.30 for the male peer groups and from around 0.03 to 0.10 for the female groups.

The second stage results suggest that men's entrepreneurship behavior is significantly affected by all the male peer groups. Female peer groups have considerably less influence on men, with statistically significant effects only for close family (mothers and sisters) and schoolmates. Women's entrepreneurship behavior is to a larger extent affected by both male and female peer groups. Yet, for schoolmates, own sex peers are much more important than those of opposite sex.

For both men and women, there is a tendency that same-sexed close neighbors are more important than distant neighbors, and that close family members are more important than distant family members. In order to interpret these comparisons, it is important to bear in mind the enormous size differences. Each group's estimated influence should be viewed in light of its size. $^{8}$ For example, the finding that close neighbors tend to be more important that distant neighbors becomes much more evident when we take into account that there are (on average) seven times as many distant as there are close neighbors.

Viewed as a whole, our estimates suggest that peer effects are of considerable importance for early career entrepreneurship. We will now use the estimated 2SLS model to assess how much of the gender gap that can be attributed to differences in peer influences. We do this by computing the hypothetical entrepreneurship behavior under the assumption that male and female peer groups were characterized by exactly the same (average) entrepreneurship rates (equal to the average of the observed male and female peer group averages). For men, we then find that the incidence of entrepreneurship would have been $9.2 \%$ instead of the observed 10.6 \%. For women, it would have been $6.9 \%$ instead of the observed 5.7. Hence, the gender gap in our outcome variable would have been 2.3 instead of 4.9 percentage points. Peer group

\footnotetext{
${ }^{8}$ See Markussen and Røed (2015) for a discussion of this in relation to peer effects in the use of social insurance.
} 
composition is thus estimated to explain 2.6 percentage points (53\%) of the observed gender gap in early career entrepreneurship behavior. Following this logic, we can examine the contribution to the gender gap provided by each of the peer group types: neighbors, family, and schoolmates. We then find that the peer group composition among neighbors are most important (explains $30 \%$ of the gender gap), followed by schoolmates (16\%) and family (7 \%).

Table 4. Estimated contributions to the gender gap in early career entrepreneurship by the differences between male and female peer groups

\begin{tabular}{|c|c|c|}
\hline & $\begin{array}{c}\text { In percentage points } \\
\text { [90\% confidence interval] }\end{array}$ & $\begin{array}{l}\text { In } \% \text { of overall gender gap } \\
\text { [90\% confidence interval] }\end{array}$ \\
\hline All peer groups & $2.57[1.05,4.01]$ & $53.0 \%[21.2,81.2]$ \\
\hline Neighbors & $1.49[0.41,2.52]$ & $30.0 \%[8.3,51.3]$ \\
\hline Family & $0.36[0.25,0.46$ & $7.2 \%[5.0,9.5]$ \\
\hline Schoolmates & $0.73[-0.38,1.77]$ & $15.8 \%[-7.8,35.7]$ \\
\hline
\end{tabular}

Note: The results in the table are based on a nonparametric bootstrap with 1000 re-samplings (with replacement) and re-estimations. The reported numbers are the mean, the $5^{\text {th }}$ percentile, and the $95^{\text {th }}$ percentile in the distributions of the respective statistics generated by these trials.

These numbers are estimated with large statistical uncertainty, however. To obtain confidence intervals on the explanatory power of peer group composition, we have performed a nonparametric (clustered) bootstrap exercise, based on 1,000 re-samplings (with replacement) and re-estimations. The results are presented in Table 4 . They show that a $90 \%$ confidence interval for the overall impact on the gender gap from peer group composition runs from around 1 to 4 percentage points (21 to $81 \%$ of the gap). The statistical uncertainty is particularly large for the role of schoolmate peer groups.

\section{Robustness and alternative outcomes}

In this section, we first assess the robustness of our findings with respect to extensions of the sets of control variables. We then estimate separate models for entrepreneurship activity in each of the 10 possible outcome years. In the latter exercise, the number of observations declines progressively as we extend the outcome period beyond five years after graduation.

One potential identification challenge comes from non-random sorting into educational programs. Some educational tracks are clearly more entrepreneur-oriented that others; and failure to control properly for education may imply that this variation is falsely interpreted as generated by schoolmate peer effects. In our baseline model, we have indeed controlled for education by means of 219 dummy variables, representing both the level, direction, and type of education, using a three digit code based on the international standard classification of education (ISCED). In a robustness analysis, we take this a step further by employing a five-digit 
code with 669 categories. The results of this exercise are presented in Table 5, columns I (men) and III (women). While most of the estimated peer effects remain more or less unchanged, the estimated effects of the schoolmate peer group becomes slightly smaller. Since many (70) of the five-digit education codes are associated with unique peer groups, this specification is likely to imply that genuine peer effects to some extent are capture by the education dummy variables.

Another potential identification challenge comes from local variations in industry composition, i.e., that typically entrepreneurial industries are more prevalent in some local areas than in others. Failure to account for this may imply that the spatial variation in entrepreneurial industries is falsely interpreted as neighborhood peer effects. To some extent, the use of education dummy variables also indirectly controls for industry composition, as many of the educations specialize for particular industries. Moreover, the use of TWA-by-year dummy variables controls non-parametrically for variations in industry composition at the commuting zone levels. Remaining variations in industry composition (within commuting zones) would also be more likely to be captured by distant than by close neighbors; hence, we interpret the larger effects arising from the (relatively few) close neighbors than from the (much larger number) of distant neighbors, as a confirmation of the peer effect interpretation. To nevertheless check this further, we also add into the model controls for the industry actually chosen by each individual. For this purpose, we use a two-digit code based on the Statistical Classification of Economic Activities in the European Community (NACE) with 88 different categories. ${ }^{9}$ In this exercise, we also need to condition on at least one industry affiliation having been observed. In practice, this means that we can only use graduates for which either an employment relationship or an entrepreneurship activity has been observed during the first five years after graduation. This reduces the sample by $17-18 \%$. The results are presented in Table 5, columns II and IV. They are very similar to those obtained in the baseline analysis. If anything, the estimated neighborhood peer effects become a bit larger than in the baseline model.

${ }^{9}$ The acronym originates from the French translation: Nomenclature statistique des Activités économiques dans la Communauté Européenne. 
Table 5. Robustness. Second stage 2SLS results (standard errors in parentheses) Dependent variable $=$ Own entrep. within five years after graduation

\begin{tabular}{|c|c|c|c|c|}
\hline & \multicolumn{2}{|c|}{ Men } & \multicolumn{2}{|c|}{ Women } \\
\hline & $\begin{array}{c}\text { I } \\
\text { Extended educa- } \\
\text { tion controls } \\
\end{array}$ & $\begin{array}{c}\text { II } \\
\text { Added industry } \\
\text { controls } \\
\end{array}$ & $\begin{array}{c}\text { III } \\
\text { Extended educa- } \\
\text { tion controls } \\
\end{array}$ & $\begin{array}{c}\text { IV } \\
\text { Added industry } \\
\text { controls } \\
\end{array}$ \\
\hline \multicolumn{5}{|l|}{ Entrep. close neighbors } \\
\hline Men & $\begin{array}{c}0.156 * * * \\
(0.015)\end{array}$ & $\begin{array}{c}0.174 * * * \\
(0.017)\end{array}$ & $\begin{array}{c}0.039 * * * \\
(0.010)\end{array}$ & $\begin{array}{c}0.043 * * * \\
(0.012)\end{array}$ \\
\hline Women & $\begin{array}{c}0.000 \\
(0.031)\end{array}$ & $\begin{array}{c}0.011 \\
(0.035)\end{array}$ & $\begin{array}{c}0.020 \\
(0.024)\end{array}$ & $\begin{array}{c}0.036 \\
(0.028)\end{array}$ \\
\hline \multicolumn{5}{|l|}{ Entrep. dist. neighbors } \\
\hline Men & $\begin{array}{c}0.083 * * * \\
(0.024)\end{array}$ & $\begin{array}{c}0.098 * * * \\
(0.027)\end{array}$ & $\begin{array}{c}0.027 \\
(0.017)\end{array}$ & $\begin{array}{l}0.037^{* *} \\
(0.019)\end{array}$ \\
\hline Women & $\begin{array}{c}0.040 \\
(0.072)\end{array}$ & $\begin{array}{c}0.075 \\
(0.081)\end{array}$ & $\begin{array}{l}0.088^{*} \\
(0.053)\end{array}$ & $\begin{array}{c}0.117 \\
(0.061)\end{array}$ \\
\hline \multicolumn{5}{|l|}{ Entrep. close family } \\
\hline Men & $\begin{array}{c}0.058 * * * \\
(0.003)\end{array}$ & $\begin{array}{c}0.061 * * * \\
(0.004)\end{array}$ & $\begin{array}{c}0.021 * * * \\
(0.003)\end{array}$ & $\begin{array}{c}0.021 * * * \\
(0.003)\end{array}$ \\
\hline Women & $\begin{array}{c}0.041^{* * *} \\
(0.007)\end{array}$ & $\begin{array}{c}0.042^{* * *} \\
(0.007)\end{array}$ & $\begin{array}{c}0.039 * * * \\
(0.006)\end{array}$ & $\begin{array}{c}0.042^{* * *} \\
(0.006)\end{array}$ \\
\hline \multicolumn{5}{|l|}{ Entrep. dist. family } \\
\hline Men & $\begin{array}{c}0.034 * * * \\
(0.005)\end{array}$ & $\begin{array}{c}0.034 * * * \\
(0.006)\end{array}$ & $\begin{array}{c}0.007 \\
(0.004)\end{array}$ & $\begin{array}{l}0.007^{*} \\
(0.004)\end{array}$ \\
\hline Women & $\begin{array}{l}-0.004 \\
(0.008)\end{array}$ & $\begin{array}{l}-0.007 \\
(0.009)\end{array}$ & $\begin{array}{c}0.017 * * \\
(0.007)\end{array}$ & $\begin{array}{c}0.018 * * \\
(0.009)\end{array}$ \\
\hline \multicolumn{5}{|l|}{ Entrep. schoolmates } \\
\hline Men & $\begin{array}{c}0.228 * * * \\
(0.087)\end{array}$ & $\begin{array}{c}0.275^{* * *} \\
(0.095)\end{array}$ & $\begin{array}{c}0.059 \\
(0.044)\end{array}$ & $\begin{array}{l}0.085^{*} \\
(0.050)\end{array}$ \\
\hline Women & $\begin{array}{c}0.239 \\
(0.151)\end{array}$ & $\begin{array}{c}0.299 * * \\
(0.172)\end{array}$ & $\begin{array}{c}0.340 * * * \\
(0.144)\end{array}$ & $\begin{array}{c}0.408 * * * \\
(0.165)\end{array}$ \\
\hline Number of observations (N) & 113,156 & 94,224 & 101,046 & 83,194 \\
\hline
\end{tabular}

Note: All regressions include indicator variables for age-at-graduation (12 categories), graduation school (1,166 categories), travel-to-work area by graduation (460 categories), and origin-region for first- and second generation immigrants (5 categories). The model in columns I and III in addition includes 669 education level/type dummy variables. The models in columns II and IV contain 219 education dummy variables (as in the baseline model) and 88 industry dummy variables. The number of observations is reduced for these latter models, as we can only use observations for which an industry has been revealed through employment and/or entrepreneurship. Standard errors are computed with a two-way cluster on neighborhood (close neighbors) and schoolmate/co-student peer group. $\left.{ }^{* * *}\right)(* * *)$ indicate statistical significance at the $10(5)(1) \%$ levels.

With respect to the fraction of the gender gap in early career entrepreneurship that can be explained by peer group composition, it is notable that the results presented in Table 5 entail almost exactly the same conclusion as the results from the baseline model in Table 3. Using the model in columns I and III (with five-digit education controls) to estimate the hypothetical entrepreneurship rates under the counterfactual assumption of equal entrepreneurship rates in male and female peer groups, our point estimates indicate that $50 \%$ of the gap in early career entrepreneurship is explained by peer group composition. Using the model in columns II and 
IV (conditional on employment or entrepreneurship), we estimate that $44 \%$ of the gender gap is explained by peer group composition.

So far, our analysis has focused entirely on the summary outcome of "some entrepreneurship within five years after graduation”, which is observed for all the graduates in our dataset. We now use our baseline model to examine peer effects on a wide range of entrepreneurship outcomes, ranging from entrepreneurship in the first year after graduation and up to the $10^{\text {th }}$ year after graduation. Each outcome is defined such that it takes the value one if entrepreneurship occurred in the year in question, and zero otherwise. Given the large number of estimates involved in this exercise, we present the results graphically; see Figures 5 (men) and 6 (women). As the number of observations declines when we exceed five years after graduation (since we lose one graduation cohort for each year we extend the outcome period), the statistical uncertainty also becomes larger.

The main point to note from the results in Figures 5 and 6 is that the overall pattern of estimated peer effects is the same regardless of when we record entrepreneurship outcomes. There is a tendency for the estimated peer effects to grow a bit as we move away from the graduation year (in line with the magnitude of the average outcome; confer Figure 3, panel (b)). 
(a) Close neighbors - males

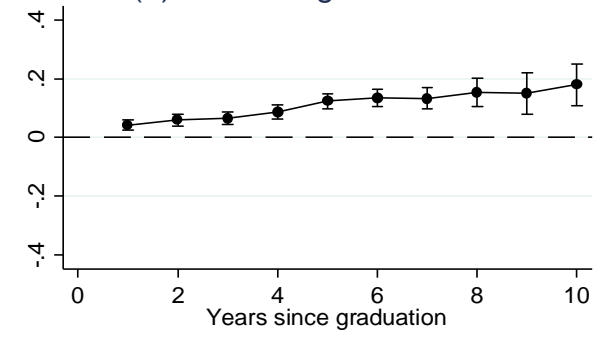

(c) Close neighbors - females

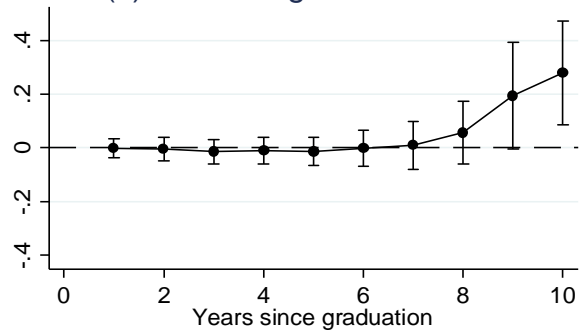

(e) Close family - males

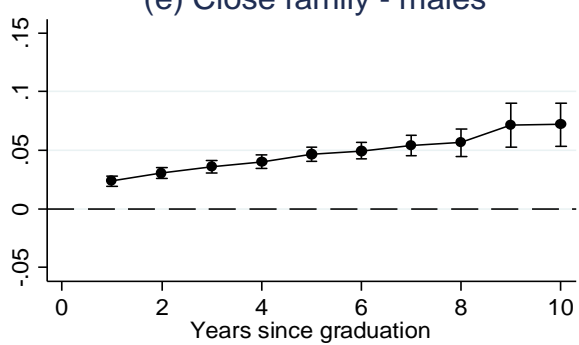

(g) Close family - females

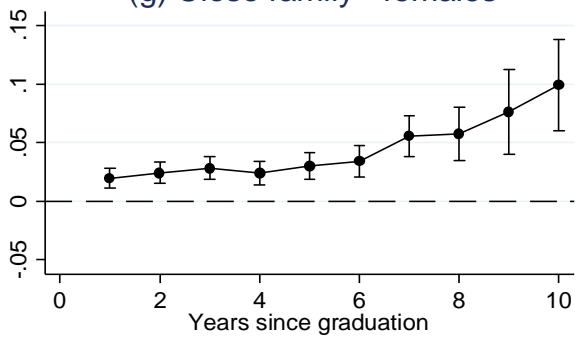

(i) Schoolmates - males

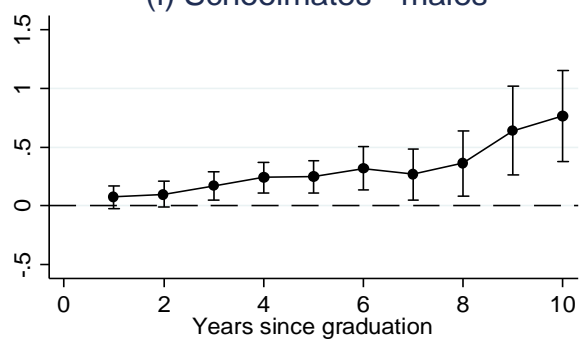

(b) Distant neighbors - males

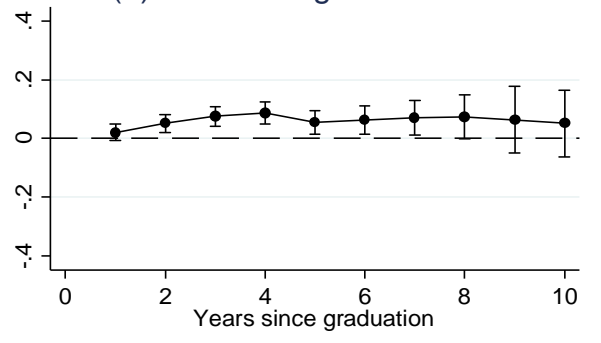

(d) Distant neighbors - females

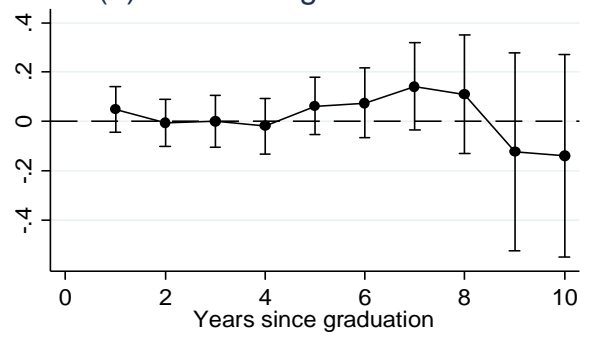

(f) Distant family - males

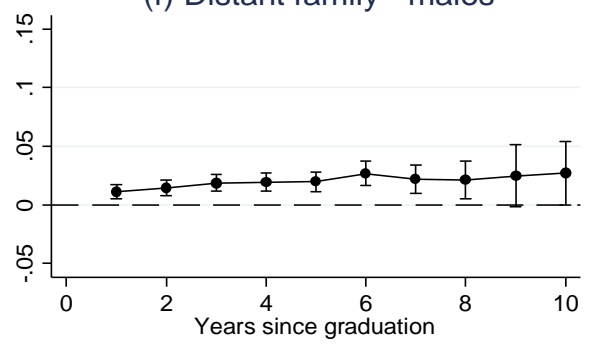

(h) Distant family - females

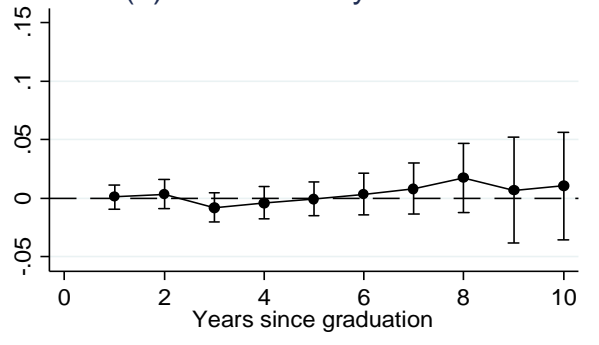

(j) School mates - females

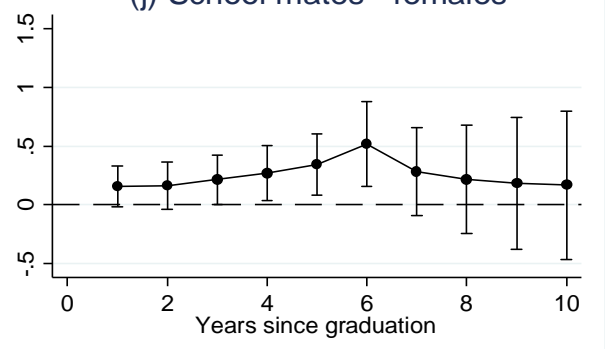

Figure 5. Estimated peer effects for men by years since graduation (with $95 \%$ confidence intervals).

Note: For each year, the outcome is equal to one if some entrepreneurship activity occurred that year, otherwise zero. See also the note to Table 3 for a description of control variables and standard error calculations. 
(a) Close neighbors - males

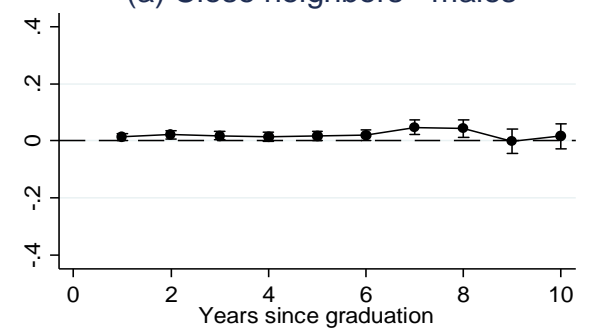

(c) Close neighbors - females

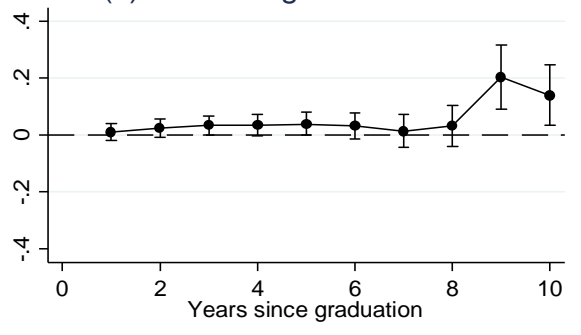

(e) Close family - males

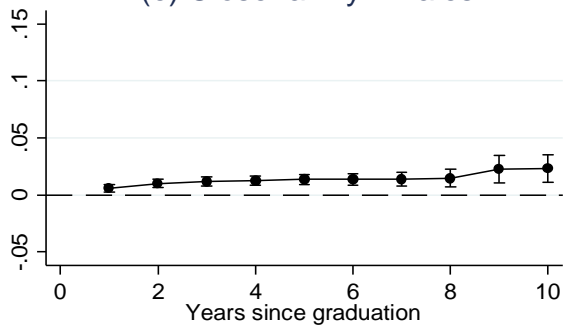

(g) Close family - females

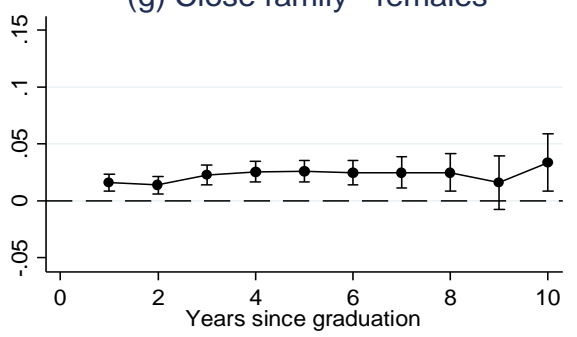

(i) Schoolmates - males

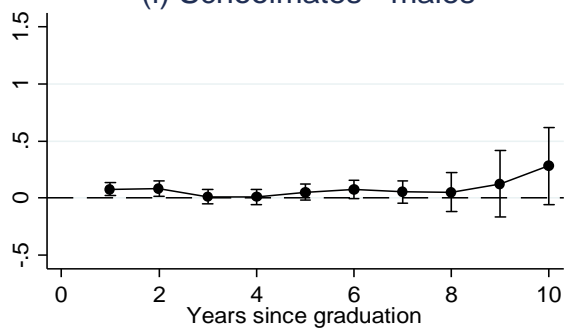

(b) Distant neighbors - males

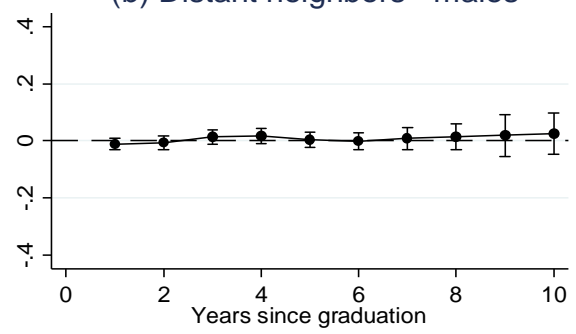

(d) Distant neighbors - females

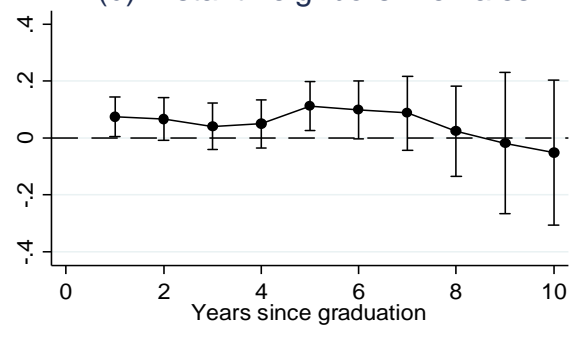

(f) Distant family - males

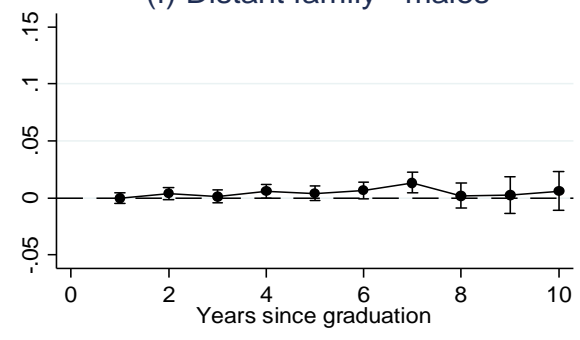

(h) Distant family - females

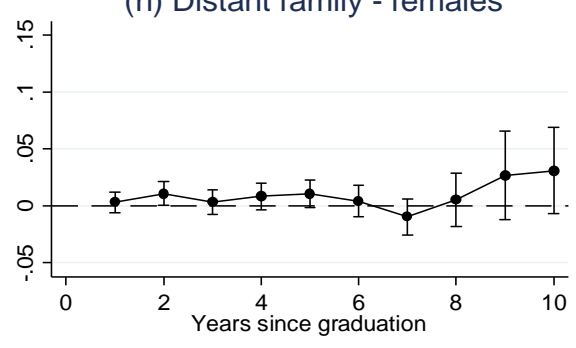

(j) School mates - females

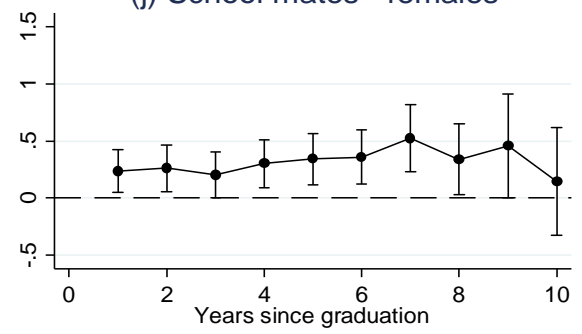

Figure 6. Estimated peer effects for women by years since graduation (with $95 \%$ confidence intervals).

Note: For each year, the outcome is equal to one if some entrepreneurship activity occurred that year, otherwise zero. See also the note to Table 3 for a description of control variables and standard error calculations. 


\section{Conclusion}

The starting point of this paper was that large gender gaps tend to prevail in entrepreneurship rates, despite increased gender equality in labor market participation patterns more generally. Attempts to explain the gender gap by means of observed individual characteristics, such as education, occupation, or industry, have indicated that a considerable gender gap remains unaccounted for. In this paper, we have examined the empirical relevance of an additional explanation, namely that the gender gap is preserved through the influences of gender-specific networks and peer effects.

Based on administrative registers from Norway, we have indeed found that early career entrepreneurship is strongly affected by existing entrepreneurship activities among family members, neighbors, and schoolmates. We have also found that these influences are heavily gendered, in the sense that men are more influenced by other men and women are more influenced by other women. Since existing entrepreneurship rates are much higher for men than for women, this mechanism represents an important source of gender gap persistence. Females are underrepresented in entrepreneurship today partly because they were underrepresented in the past. Assuming (counterfactually) that male and female peer-groups and (older) family members had exactly the same entrepreneurship rates (equal to the average of the two observed gender-specific rates), our model predicts that the gender gap in early career entrepreneurship would have been cut by $53 \%$ (with a $90 \%$ confidence interval ranging from 21 to $81 \%)$.

Although we will argue that the analysis in this paper convincingly establishes the existence of gendered peer influences, a potential limitation is that we cannot disentangle endogenous social interactions from contextual peer effects (Manski, 1993). While the former (endogenous interactions) represents a situation where some individuals are influenced by other individuals' actual entrepreneurship behavior, the latter (contextual effects) represents a situation where individuals are influenced directly by the characteristics that caused these other persons' behavior in the first place. This distinction may be important from a policy perspective, since endogenous interactions imply the existence of direct knock-on effects in entrepreneurship propensity, in the sense that if, for example, it is possible to encourage at least some extra women to become entrepreneurs through some policy tool, this will subsequently trigger additional female entrepreneurship via the endogenous social interaction effect. In practice, the distinction between these two mechanisms is blurred, as a person's own entrepreneurship ex- 
periences most likely feed into own preferences and attitudes, which again become the source of additional contextual peer effects. Hence, we interpret the evidence in this paper as suggestive of a considerable social multiplier: Raising the number of female entrepreneurs "now" will make entrepreneurship more tempting and/or more feasible for other women in the future. It should also be noted that the peer groups identified in this paper are imperfect proxies for actual social networks. Hence, our assessment of the overall explanatory power of peer effects in explaining the gender gap is likely to underestimate their true influence.

\section{References}

Alsos, G. A. og Ljunggren, E. (2006) Kjønn og entreprenørskap. I Spilling, O. R. (red.) Entreprenørskap på norsk, kapittel 10. Fagbokforlaget. Bergen.

Andersson, M. and Larsson, J. P. (2016) Local Entrepreneurship Clusters in Cities. Journal of Economic Geography, Vol. 16, No. 1, 39-66.

Angrist, J. (2013) The perils of peer effects. NBER Working Paper No. 19774

Bauernschuster, S., Falck, O. and Heblich, S. (2010), Social Capital Access and Entrepreneurship. Journal of Economic Behavior \& Organization, Vol. 76, 821-833.

Berglann, H., Golombek, R. and Røed, K. (2013) Entreprenørskap i Norge - Mest for Menn? Søkelys på arbeidslivet, Vol. 30, No. 1-2, 3-21.

Berglann, H., Moen, E., Røed, K. and Skogstrøm, J. F. (2011) Entrepreneurship: Origins and Returns. Labour Economics, Vol. 18, 180-193.

Bhuller, M.S. (2009) Inndeling av Norge i arbeidsmarkedsregioner, Notater 2009/24, Statistics Norway.

Bönte, W. and Piegeler, M. (2013) Gender Gap in Nascent Entrepreneurship: Driven by Competitiveness. Small Business Economics, Vol. 41, 961-987.

Borghans, L., Golsteyn, B. H. H. , Heckman, J. J. og Meijers, H. (2009) Gender Differences in Risk Aversion and Ambiguity Aversion. Journal of the European Economic Association, Vol. 7 (2-3), 649-658. 
Bosma, N., Hessels, J., Schutjens, V., Van Praag, M. and Verheul, I. (2012) Entrepreneurship and Role Models. Journal of Economic Psychology, Vol. 33, 410-424.

Byrnes, J. P., Miller, D. C. and Schafer, W. D. (1999) Gender Differences in Risk Taking: A Meta-analysis. Psych Bull, Vol. 125, 367-383.

Croson, R. og Gneezy, U. (2009) Gender Differences in Preferences. Journal of Economic Literature, Vol. 47 (2), 1-27.

Fritsch, M. and Wyrwich, M. (2014) The Long Persistence of Regional Levels of Entrepreneurship - Germany, 1925-2005. Regional Studies, Vol. 48, No. 6, 955-973.

Giannetti, M. and Simonov, A. (2009) Social Interactions and Entrepreneurial Activity. Journal of Economics and Management Strategy, Vol. 18, No. 3, 665-709.

Gneezy, U., Niederle, M. and Rustichini, A. (2003) Performance in Competitive Environments: Gender Differences. Quarterly Journal of Economics, Vol. 118 (3), 10491074.

Guiso, L., Pistaferri, L, and Schivardi, F. (2015) Learning Entrepreneurship from Other Entrepreneurs? NBER Working Paper Series 21775.

Jianakoplos, N. A. and Bernasek, A. (1998) Are Women More Risk Averse? Economic Inquiry, Vol. 36 (4), 620-630.

Kelley, D. J., C. G. Brush, P. G. Greene og Y. Litovsky (2012) Global Entrepreneurship Monitor - 2012 Women’s Report.

Lindquist, M. J., Sol, J. and Van Praag, M. (2015) Why Do Entrepreneurial Parents Have Entrepreneurial Children? Journal of Labor Economics, Vol. 33, No. 2, 269-296.

Manski, C. F. (1993) Identification of Endogenous Social Effects: The Reflection Problem. The Review of Economic Studies, Vol. 60 (3), 531-42.

Markussen, S. and Røed, K. (2015) Social Insurance Networks, Journal of Human Resources, Vol. 50, No. 4, 1081-1113.

Nada, R. and Sørensen, J. B. (2008) Workplace Peers and Entrepreneurship. Working Paper No. 08-051. Harvard Business School. 
Niederle, M. and Vesterlund, L. (2007) Do Women Shy Away from Competition? Do Men Compete Too Much? Quarterly Journal of Economics, Vol. 122 (3), 1067-1101.

Ruef, M., Aldrich, H. E., and Carter, N. C. (2003) The Structure of Founding Teams: Homophily, Strong Ties, and Isolation among US Entrepreneurs. American Sociological Review, Vol. 68, 195-222

Sanderson, E. and Windmeijer, F. (2016) A Weak Instrument F -test in Linear IV models with Multiple Endogenous Variables. Journal of Econometrics, Vol. 190, 212-221.

Sapienza, P., Zingales, L. and Maestripieri, D. (2009) Gender Differences in Financial Risk Aversion and Career Choices are Affected by Testosterone. Proceedings of the National Academy of Sciences USA (PNAS), 106 (36), 15268-15273.

Statistics Norway. (1999) Regionale inndelinger - En oversikt over standarder i norsk offisiell statistikk. Norges Offisielle Statistikk, Oslo-Kongsvinger.

Stock, J. H., Yogo, M. (2005) Testing for weak instruments in linear IV regression. In: Andrews, D.W.K., Stock, J.H. (Eds.), Identification and Inference for Econometric Models, Essays in Honor of Thomas Rothenberg. Cambridge, University Press, New York, 80-108.

Verheul, I., Thurik, R., Grilo, I. and van der Zwan, P. (2012) Explaining Preferences and Actual Involvement in Self-Employment: Gender and the Entrepreneurial Personality. Journal of Economic Psychology, Vol. 33, 325-341. 